\title{
Primary Leiomyoma of the pleura
}

\author{
Xiaoming Qiu, Daxin Zhu, Sen Wei, Gang Chen, Jun Chen ${ }^{*}$ and Qinghua Zhou ${ }^{*}$
}

\begin{abstract}
Primary leiomyoma of the pleura is extremely rare. A 45-year-old man presented with a complaint of right chest pain. Chest computed tomography demonstrated a solid, round pleural mass in the right anterior chest wall. The mass was completely resected, and histopathological examination revealed a localized primary pleural leiomyoma. The patient was followed and has been disease-free for over 15 months. This is the first report of primary leiomyoma of the pleura in China. A review of the literature on primary leiomyoma of the pleura is presented.
\end{abstract}

Keywords: Pleural tumor, Leiomyoma, Smooth muscle tumor

\section{Introduction}

Leiomyomas are benign smooth muscle tumors that are commonly encountered in the urogenital tract, occasionally in the gastrointestinal tract, and rarely in the respiratory tract [1]. However, leiomyomas originating from the pleura are extremely rare. To our knowledge, only 8 cases have been published up to the present time. Here, we present the first primary pleural leiomyoma in China.

\section{Case report}

A 45-year-old man without any significant past history was admitted to our department complaining of right chest pain persisting for 3 days. A mass was seen in the right middle lung field on chest roentgenogram (Figure 1A). However, physical examination was unremarkable. Computed tomography showed a solid, round pleural mass measuring $5.9 \mathrm{~cm} \times 8 \mathrm{~cm} \times 6.2 \mathrm{~cm}$ located in the right anterior chest wall, with " heterogeneous density and calcification. It was well capsulated and compressed the lung parenchyma without any sign of infiltration of the lung or chest wall (Figure 1B).

The patient underwent a right posterolateral thoracotomy. A giant, well-capsulated smooth-surfaced tumor was observed in the anterior chest wall. It was easily resected en-bloc with surrounding tissue. Grossly, the tumor measured $9 \mathrm{~cm} \times 6 \mathrm{~cm} \times 5 \mathrm{~cm}$ and was covered with pleura. The cut tumor was solid white with cystic cavities. Pathological examination revealed a

\footnotetext{
* Correspondence: huntercj2004@yahoo.com; zhouqh1016@yahoo.com.cn Department of Lung Cancer Surgery, Tianjin Key Laboratory of Lung Cancer Metastasis and Tumor Microenvironment, Tianjin Lung Cancer Institute, Tianjin Medical University General Hospital, Tianjin 300052, China
}

proliferation of interlaced fascicles of spindle cells showing moderate atypia and less than 1 mitotic figure per 50 high power fields (Figure 2). Immunohistochemistry revealed diffuse and strong staining for both smooth muscle actin (SMA) and desmin (Figure 2). Tumor tissue stained negative for estrogen receptor, progesterone receptor, CD117, and $\mathrm{HMB} 45$, and was weakly positive for S-100 protein (data not shown).

The patient had an uneventful recovery, and there has been no sign of recurrence 15 months after surgery. Since the malignant potential of the tumor could not be determined, close follow-up of the patient was advised.

\section{Discussion}

Primary intrathoracic soft tissue tumors are unusual. They can originate from the upper or lower respiratory tract or from the mediastinum. The differential diagnosis for pleural spindle cell neoplasms includes solitary fibrous tumor, smooth muscle tumor, spindle cell carcinoma, thymoma, sarcomatoid variant of mesothelioma, and leiomyoid variant of mesothelioma [2-5]. Leiomyomas commonly originating from urogenital tract and gastrointestinal tract are most benign smooth muscle tumors, and rarely originates from respiratory tract and pleura. So far, there were only 8 primary pleural leiomyomas reported in the world [1,6-11]. Table 1 summarizes patient and tumor characteristics of the 8 previously described cases and our case. Of these cases, 6 were asymptomatic and 3 had nonspecific chest pain related to tumor size and location. The tumor appears to occur more frequently in young to middle-aged females (6 of nine cases).
C Biomed Central

(ㄷ) 2011 Qiu et al; licensee BioMed Central Ltd. This is an Open Access article distributed under the terms of the Creative Commons Attribution License (http://creativecommons.org/licenses/by/2.0), which permits unrestricted use, distribution, and reproduction in any medium, provided the original work is properly cited. 


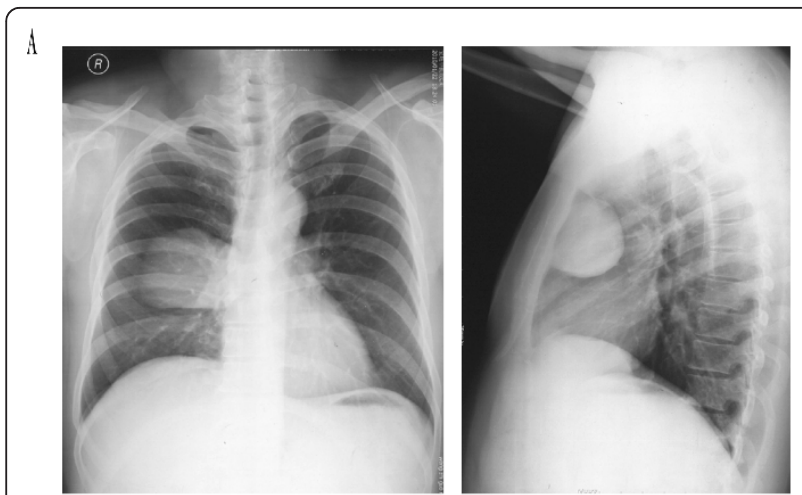

B

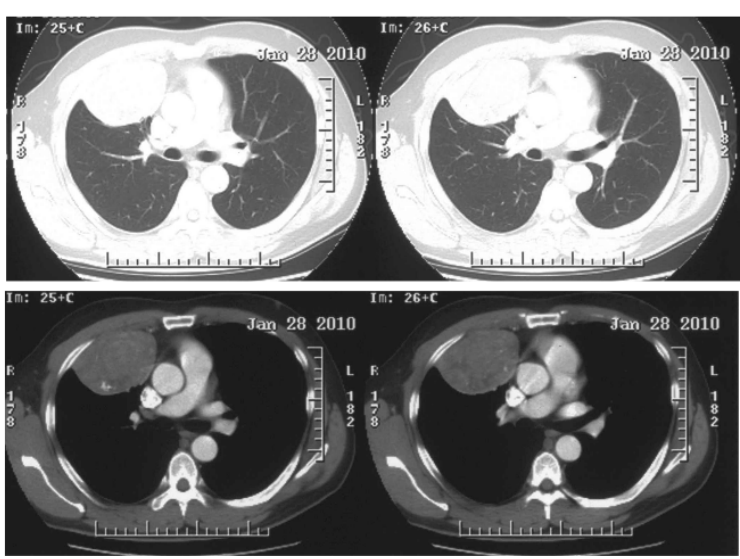

Figure $\mathbf{1}$ Chest images (A) Chest radiograph. A mass is seen in the right middle lung field on chest roentgenogram; (B) Chest contrast enhanced computed tomography scans. A solid, round pleural mass is seen in the right anterior chest wall, with heterogeneous density and calcification. It is well capsulated and compresses the lung parenchyma without any sign of infiltration of lung or chest wall.

Although this leiomyoma of the pleura appeared benign, with a smooth, well-capsulated surface and unremarkable histologic findings, it has a low but definite malignant potential. Pleural leiomyomas may increase in size with local invasion to the mediastinum and may not be possible to resect completely [7]. They may even metastasize or disseminate through the needle tract years after a transthoracic fine-needle biopsy [1]. Computed tomography-guided transthoracic fine-needle aspiration (FNA) of chest wall tumors is preferred by oncologists, in order to obtain an accurate preoperative tissue diagnosis by histopathological examination $[12,13]$. Although FNA can be easily performed for most chest tumors, with minimal damage to the primary tumor and low rates of complications, to avoid needle seeding, we believe that FNA should not be performed if the tumor can be resected completely. It should only be performed when the tumor is unresectable or the patient refuses surgery, in order to allow pathologic diagnosis for further medical treatment.

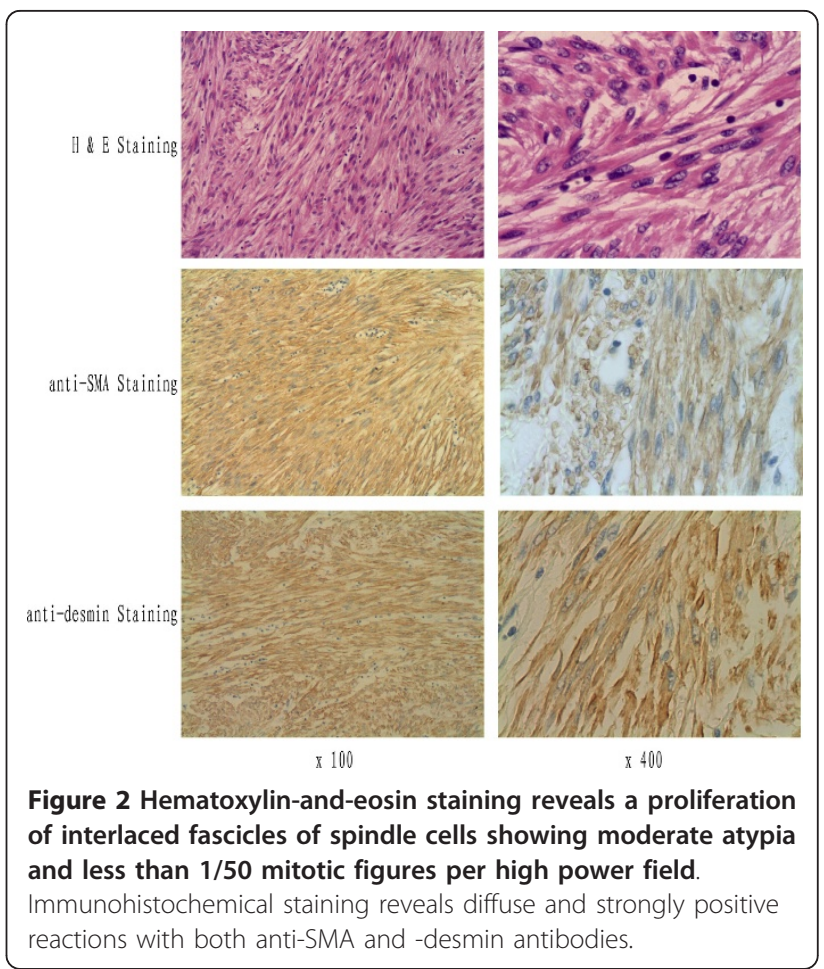

Most tumors can be completely resected if the contrast-enhanced chest CT scan shows a well-capsulated pleural mass with minimal invasion of the adjacent organs, and the patient does not have signs of invasion, such as very severe pain. In general, most primary pleural leiomyomas can be easily and completely resected. If the tumor is small and localized, complete resection can be achieved with minimally invasive surgery such as video-assisted thoracic surgery (VATS) $[8,9,14]$. In addition, the prognosis is fairly good for patients in whom the tumor is completely resected. The presence of smooth muscle fibers without signs of malignancy (pleomorphism, mitotic figures, and poor differentiation) can be confirmed by hematoxylin and eosin (H\&E) staining. Immunohistochemical staining should be positive for SMA, vimentin, desmin, and HH35 soft muscle protein [1,13]. The histological features of H\&E-stained tissue sections plus positive staining for SMA and desmin provide unambiguous evidence for the diagnosis of primary pleural leiomyoma.

\section{Conclusion}

In summary, because primary pleural leiomyoma is an extremely rare tumor with low malignant potential, complete resection and close follow-up is advised. Transthoracic fine-needle biopsy is contraindicated if it is possible that the tumor can be completely resected. 
Table 1 Clinical features of published case reports of primary pleural leiomyoma

\begin{tabular}{|c|c|c|c|c|c|c|}
\hline Case & Author & $\begin{array}{l}\text { Gender/ } \\
\text { age }\end{array}$ & Clinical manifestations & Clinical course & Tumor size $(\mathrm{cm})$ & $\begin{array}{l}\text { Follow-up } \\
\text { after } \\
\text { operation }\end{array}$ \\
\hline 1 & $\begin{array}{l}\text { Tanaka T et } \\
\text { al [6] }\end{array}$ & $F / 40$ & Asymptomatic & Complete resection & $3,5 \times 3,0$ & $\begin{array}{l}17 \text { months } \\
\text { Alive without } \\
\text { recurrence }\end{array}$ \\
\hline 2 & $\begin{array}{l}\text { Moran CA } \\
\text { et al [7] }\end{array}$ & $F / 21$ & $\begin{array}{l}\text { Asymptomatic, large left pleural } \\
\text { tumor involving diaphragm }\end{array}$ & Too large for complete resection & $\begin{array}{l}\text { Multiple fragments } \\
\text { of firm, grey tissues }\end{array}$ & $\begin{array}{l}4 \text { months } \\
\text { Alive }\end{array}$ \\
\hline 3 & $\begin{array}{l}\text { Moran CA } \\
\text { et al [7] }\end{array}$ & $F / 23$ & $\begin{array}{l}\text { Asymptomatic, } \\
\text { large mass arising from the right } \\
\text { pleura }\end{array}$ & Too large for complete resection & $10.0 \times 9.0 \times 5.5$ & $\begin{array}{l}6 \text { months } \\
\text { Alive }\end{array}$ \\
\hline 4 & $\begin{array}{l}\text { Proca DM } \\
\text { et al [1] }\end{array}$ & $M / 32$ & Asymptomatic & $\begin{array}{l}\text { Resected } 4 \text { years after needle biopsy, when } \\
\text { enlarged and invading the chest wall }\end{array}$ & $4.3 \times 7.0$ & $\begin{array}{l}12 \text { months. } \\
\text { Alive without } \\
\text { recurrence }\end{array}$ \\
\hline 5 & $\begin{array}{l}\text { Mochizuki } \\
\mathrm{H} \text { et al }[8]\end{array}$ & $M / 33$ & Asymptomatic & Complete resection with VATS & $3 \times 2$ & Unknown \\
\hline 6 & $\begin{array}{l}\text { Nose } N \text { et } \\
\text { al [9] }\end{array}$ & $F / 55$ & Asymptomatic & Complete resection with VATS & $1.5 \times 1.5$ & $\begin{array}{l}26 \text { months } \\
\text { Alive without } \\
\text { recurrence }\end{array}$ \\
\hline 7 & $\begin{array}{l}\text { Turhan } \mathrm{K} \text { et } \\
\quad \text { al [10] }\end{array}$ & $\mathrm{F} / 50$ & Chest pain & Complete resection & $4.0 \times 4.0$ & $\begin{array}{l}53 \text { months } \\
\text { Alive without } \\
\text { recurrence }\end{array}$ \\
\hline 8 & $\begin{array}{l}\text { Rodriguez, } \\
\text { PM [11] }\end{array}$ & $F / 48$ & Chest pain & Complete resection & $18 \times 14 \times 11$ & $\begin{array}{l}18 \text { months } \\
\text { Alive without } \\
\text { recurrence }\end{array}$ \\
\hline 9 & Our case & $M / 45$ & Chest pain & Complete resection & $9 \times 6 \times 5$ & $\begin{array}{l}15 \text { months } \\
\text { Alive without } \\
\text { recurrence }\end{array}$ \\
\hline
\end{tabular}

VATS, video-assisted thoracic surgery.

\section{Consent}

Written informed consent was obtained from the patient for publication of this Case report and any accompanying images. A copy of the written consent is available for review by the Editor-in-Chief of this journal.

\section{Acknowledgements}

This work was supported by grants from National Natural Science Foundation of China (30670922), "863"(2006AA02A401), "973"(2010CB529405), Major Project of Tianjin Sci-Tech Support Program (07SYSYSF05000), and Key Project of Tianjin Sci-Tech Support Program (06YFSZSF05300) to Qinghua Zhou.

\section{Authors' contributions}

$X \mathrm{Q}, \mathrm{DZ}, \mathrm{JC}$ and $\mathrm{QZ}$ did the surgery, SW and GC collected the data. XQ, JC and QZ wrote the article. All authors read and approved the final manuscript.

\section{Competing interests}

The authors declare that they have no competing interests.

Received: 19 April 2011 Accepted: 14 July 2011 Published: 14 July 2011

\section{References}

1. Proca DM, Ross P Jr, Pratt J, Frankel WL: Smooth muscle tumor of the pleura. A case report and review of the literature. Arch Pathol Lab Med 2000, 124:1688-1692.

2. Khalifa MA, Montgomery EA, Azumi N, Gomes MN, Zeman RK, Min KW, Lack EE: Solitary fibrous tumors: a series of lesions, some in unusual sites. South Med J 1997, 90:793-799.
3. Gannon BR, O'Hara CD, Reid K, Isotalo PA: Solitary fibrous tumor of the anterior mediastinum: a rare extrapleural neoplasm. Tumori 2007, 93:508-510.

4. Xue X, Chen J, Ma W, Zhu D, Zhang W, Chen G, Wei S, Zhou Q: Mediastinal solitary fibrous tumor with right diaphragm invasion: report of a case. Surg Today 2009, 39:332-334.

5. Van Kolen KPL, Heyman S, Pauwels P, Van Schil P: Prognostic factors and genetic markers in thymoma. Thoracic Cancer 2010, 1:133-140.

6. Tanaka T, Adachi A, Iwata S, Nishimura Y, Tanaka Y, Kakegawa T: [A case of leiomyoma of the chest wall]. Nippon Kyobu Geka Gakkai Zasshi 1992, 40:1721-1724

7. Moran CA, Suster S, Koss MN: Smooth muscle tumours presenting as pleural neoplasms. Histopathology 1995, 27:227-234.

8. Mochizuki H, Okada T, Yoshizawa H, Suzuki E, Gejyo F: [A case of primary pleural leiomyoma]. Nihon Kokyuki Gakkai Zasshi 2004, 42:625-628.

9. Nose N, Inoue M, Kodate M, Kawaguchi M, Yasumoto K: Leiomyoma originating from the extrapleural tissue of the chest wall. Jpn J Thorac Cardiovasc Surg 2006, 54:242-245.

10. Turhan KCA, Cagirici U: Leiomyoma: an unusual pleural tumor:report of a case. Turk Resp J 2008, 9:53-55.

11. Rodriguez PM, Freixinet JL, Plaza ML, Camacho R: Unusual primary pleural leiomyoma. Interact Cardiovasc Thorac Surg 2010, 10:441-442.

12. Karapolat S: Leiomyoma: an Unusual Pleural Tumor: Letters to the Editor. Turk Resp J 2008, 9:193.

13. Al-Daraji WI, Salman WD, Nakhuda Y, Zaman F, Eyden B: Primary smooth muscle tumor of the pleura: a clinicopathological case report with ultrastructural observations and a review of the literature. Ultrastruct Pathol 2005, 29:389-398.

14. Lv X, Luo WZ, Wang YQ, Chen X, Tu ZL: Bilateral thoracotomy for removal of uncommon postmediastinal multi-schwannomas. Thoracic Cancer 2010, 1:130-132

doi:10.1186/1477-7819-9-76

Cite this article as: Qiu et al:: Primary Leiomyoma of the pleura. World Journal of Surgical Oncology 2011 9:76. 